\title{
Comparative analysis of morphological, mineralogical and spectral properties of cryoconite in Jakobshavn Isbræ, Greenland, and Canada Glacier, Antarctica
}

\author{
M. TEDESCO,${ }^{1,2}$ C.M. FOREMAN, ${ }^{3}$ J. ANTON, ${ }^{2}$ N. STEINER, ${ }^{2}$ T. SCHWARTZMAN $^{1}$ \\ ${ }^{1}$ The City College of New York, The City University of New York, New York, NY, USA \\ E-mail: mtedesco@ccny.cuny.edu \\ ${ }^{2}$ The Graduate Center of The City University of New York, New York, NY, USA \\ ${ }^{3}$ Center for Biofilm Engineering and the Department of Land Resources and Environmental Sciences, \\ Montana State University, Bozeman, MT, USA
}

\begin{abstract}
We report the results of a comparative analysis focusing on grain size, mineralogical composition and spectral reflectance values $(400-2500 \mathrm{~nm})$ of cryoconite samples collected from Jakobshavn Isbræ, West Greenland, and Canada Glacier, McMurdo Dry Valleys, Antarctica. The samples from the Greenland site were composed of small particles clumped into larger rounded agglomerates, while those from the site in Antarctica contained fragments of different sizes and shapes. Mineralogical analysis indicates that the samples from Jakobshavn Isbræ contained a higher percentage of quartz and albite, whereas those from Canada Glacier contained a higher percentage of amphibole, augite and biotite. Spectral measurements confirmed the primary role of organic material in reducing the reflectance over the measured spectrum. The reflectance of the samples from the Antarctic site remained low after the removal of organic matter because of the higher concentration of minerals with low reflectance. The reflectance of dried cryoconite samples in the visible region was relatively low (e.g. between $\sim 0.1$ and $\sim 0.4$ ) favouring increased absorbed solar radiation. Despite high reflectance values in the shortwave infrared region, the effect of the presence of cryoconite is negligible at infrared wavelengths where ice reflectance is low.
\end{abstract}

\section{INTRODUCTION}

Cryoconites are mini-entombed ecosystems existing on the surface of glaciers worldwide, composed of mineral sediments, biota and organic material (e.g. Wharton and others, 1981, 1985; Takeuchi and others, 2000; Fountain and others, 2004; Foreman and others, 2007; Bøggild and others, 2010). The Swedish explorer N. Nordenskjöld coined the term 'cryoconite' on returning from his 1870 Greenland expedition, from the combination of the Greek words 'kryos' meaning cold and 'konis' meaning dust. Cryoconite is distinct from other forms of glacier cover (e.g. moraine and loess) in that it contains a variable percentage of organic components that are specific to the location and altitude and can be of extraglacial or englacial origin. Extraglacial cryoconite can originate from rockfall onto the ice surface (Reznichenko and others, 2010) or from transport driven by circulation systems (e.g. Bøggild and others, 2010). Cryoconite of englacial origin comes from the release of debris trapped within glaciers as melting occurs, and may also consist of debris that was originally sourced subglacially or extraglacially (Nansen and H., 1891; Odell, 1925; Reznichenko and others, 2010; Wientjes and others, 2011). There are also reports of Arctic cryoconite containing soot from forest fires (Kim and others, 2005), cosmic debris (Pillinger and others, 1993; Kurat and others, 1994) and anthropogenic particulates (Pfirman and others, 1995; Meese and others, 1997; Bossew and others, 2006, 2007; Tieber and others, 2009).

Cryoconites have been shown to contain viral-like particles, bacteria, nanoflagellates, ciliates (Säwström and others, 2002; Christner and others, 2003; Anesio and others, 2007; Foreman and others, 2007) and microfauna such as tardigrades, rotifers (Takeuchi and others, 2000; Porazinska and others, 2004; Dastych, 2005), protozoans, copepods, insect larvae (Kohshima, 1984; Kikuchi, 1994), algae and cyanobacteria (Wharton and others, 1981, 1985; Mueller and others, 2001). Organic constituents can be categorized into viable and residual categories. The viable portion consists of microbes, whereas residual organic debris or 'humus' is composed of polymeric compounds resulting from microbial waste (Hodson and others, 2010a). This is the agent that binds inorganic clasts together and causes cryoconite grains to grow in size over time. Takeuchi (2002) cites the humic constituent of cryoconites as a principal instigator of snow and ice melt.

Because of the relatively darker surface of cryoconite with respect to the surrounding snow or glacier ice, the presence of cryoconite on a glacier can enhance surface melting through increased absorption of solar radiation. There are also other processes through which cryoconite might contribute to melting. Microbial organisms within cryoconite create heat energy through metabolic activities, further promoting hole development (Takeuchi, 2002; Fountain and others, 2004) and, consequently, lowering the surface albedo at small spatial scales (Kikuchi, 1994). Moreover, microbial exudates (i.e. humic detritus) are composed of polymeric compounds such as polyethylene and benzene that preferentially absorb shortwave radiation (350-550 nm) due to their dark colour (Takeuchi, 2002), potentially further contributing to additional snow and ice loss.

Surface debris may aggregate over time as a consequence of melting caused by the increased ability of cryoconites to absorb solar radiation with respect to the surrounding snow or ice surfaces. This melting around the cryoconite grains 


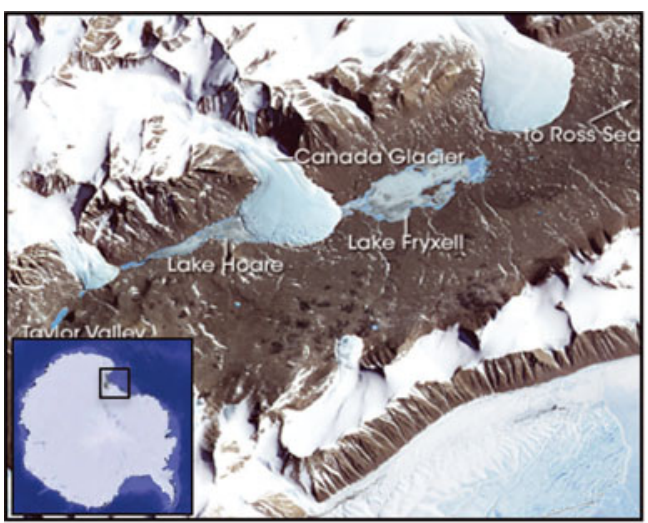

a

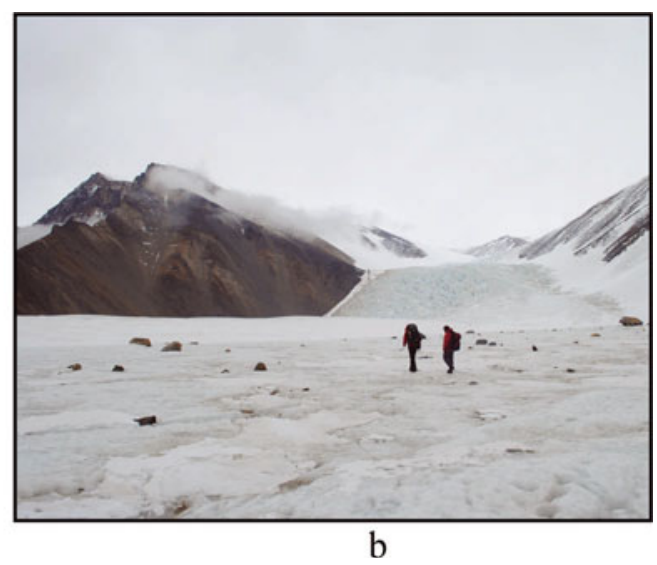

Fig. 1. (a) Location of the Antarctic sampling site, Canada Glacier; and (b) image of the site where cryoconite material was collected. Source for (a): http://earthobservatory.nasa.gov/IOTD/view.php?id=35535

allows them to group in holes, which continue to melt downward until they reach an equilibrium state wherein the depth balances the decreased albedo caused by the dust and biogenic material (Gribbon, 1979; Fountain and others, 2004; Bagshaw and others, 2007).

Arctic and Antarctic cryoconite holes exhibit different behaviour. Because energy-balance conditions favour frozen surfaces and internal melting (Fountain and Tranter, 2008), cryoconite holes in Antarctica were found to be covered by $30-40 \mathrm{~cm}$ thick ice lids over periods of observation spanning several years to decades (Tranter and others, 2004), whereas those in the Arctic form and evolve as pools of surface water open to the atmosphere, remaining uncovered for most of the melting season. The study by Fountain and others (2004) of Antarctic ice-capped cryoconite holes reveals very different properties from those previously studied in Arctic environments. The ice-lidded Antarctic cryoconite holes were highly pressurized and showed seasonal evolution of freezing and melt. Holes from Antarctica varied in depth from 4 to $56 \mathrm{~cm}$ and in width from 4 to $145 \mathrm{~cm}$ (Porazinska and others, 2004; Fountain and others, 2008).

In recent years, many studies have focused on analysing physical and spectral properties of cryoconites at different locations (e.g. Takeuchi and others, 2000; Fountain and others, 2004; Bøggild and others, 2010), but the body of literature focusing on the comparison between cryoconites from sites in the two polar regions remains relatively small (Mueller and others, 2001; Mueller and Pollard, 2004). Comparing cryoconite properties from Arctic and Antarctic sites is important to improve our understanding of the spatiotemporal evolution of cryoconite in the context of different and wide-ranging environmental settings, to study how cryoconites are impacting (or are eventually impacted by) surface processes, and to determine how this information can be employed to advance the reliability of surface massand energy-balance model estimates and predictions.

In this study, we report results concerning spectral, physical and mineralogical properties of cryoconite samples collected over Jakobshavn Isbræ, West Greenland, and Canada Glacier, McMurdo Dry Valleys, Antarctica, during the boreal and austral summers of 2010. In particular, we compare the distribution of grains from the samples collected at the two polar sites using digital photography and imageprocessing software and report the mineralogical composition of the two samples. We also study the reflectance spectra in the $400-2500 \mathrm{~nm}$ region before and after the removal of organic material through combustion, and focus on relating their spectral properties to the mineralogy.

\section{METHODS AND MATERIALS}

\section{Sampling procedure}

Samples of cryoconite material from the Antarctic site were collected on 18 December 2010 from the surface of Canada Glacier $\left(77.6166^{\circ} \mathrm{S}, 163.1833^{\circ} \mathrm{E}\right)$. Canada Glacier flows southeast into Taylor Valley, one of the three dry valleys in the Transantarctic Mountains, west of McMurdo Sound (Fig. 1a and b). The area of the dry valleys is $\sim 4800 \mathrm{~km}^{2}$ and represents the largest ice-free region in Antarctica, cutting through the Beacon Sandstone geological formation. Samples from the Greenland site were collected on 4 July 2010 at $68.5755^{\circ} \mathrm{N}, 49.3622^{\circ} \mathrm{W}$, south of Jakobshavn Isbræ (Fig. 2). The sampling site was $\sim 50 \mathrm{~km}$ from the ice edge and surrounded by supraglacial lakes. A recent study focusing on an area in South Greenland suggests that the observed dark region is probably caused by outcropping ice that contains high amounts of local dust from periods when more dust settled in the accumulation zone of the ice sheet (Wientjes and others, 2011).

For each site, multiple samples were collected from different holes (eight holes in Greenland and four holes in Antarctica). The holes in Antarctica had a similar diameter of $\sim 20 \mathrm{~cm}$ and were covered by an ice lid $\sim 20 \mathrm{~cm}$ thick (Fig. 3a and b). Conversely, the holes in Greenland were open (Fig. 3c) and had diameters ranging from a few centimetres to $40 \mathrm{~cm}$. For each collected sample, the material was stored in $250 \mathrm{~mL}$ polyethylene bottles and placed in a container (Greenland) or a freezer (Antarctica). The samples were then shipped to Kangerlussuaq International Science Station in the case of Greenland and to McMurdo station in the case of Antarctica, where they were dried in an oven. The dried material was then shipped to our laboratory for analysis.

\section{Mineralogy and grain size}

For the mineralogical analysis, samples were prepared as $30 \mathrm{~mm}$ diameter polished sections. A polyethylene pill-vial was first made of each sample and after curing in coldmounting epoxy, the vial was cut in half longitudinally. Each counterpart was then re-mounted face down to account for any density fractionation during potting, mixing and curing. 


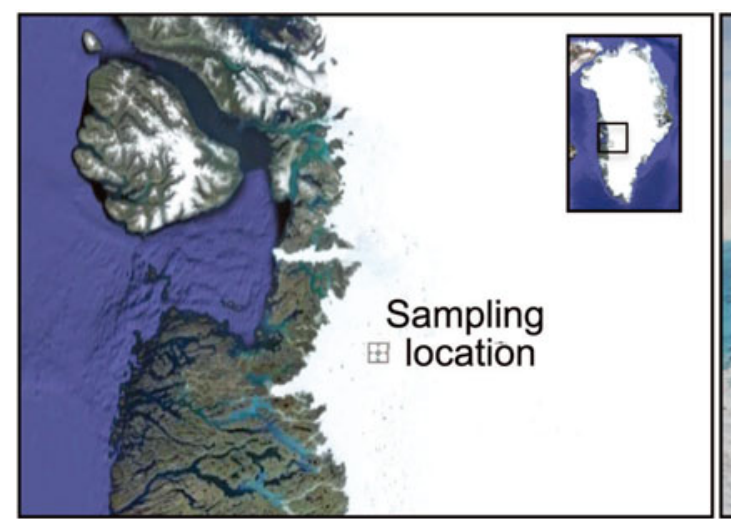

a

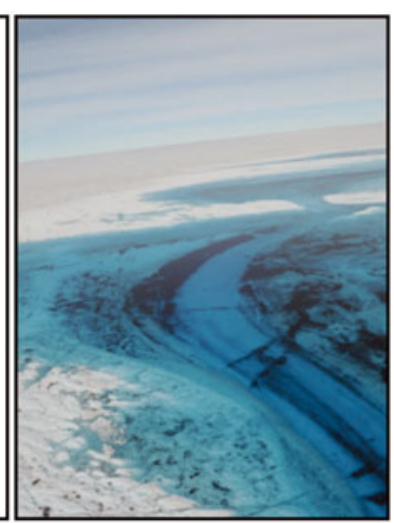

b

Fig. 2. (a) Location of the Greenland sampling site and (b) image of the site where cryoconite material was collected.

Minerals and other attributes are measured using a mineral liberation analyzer (MLA), a quantitative mineralogical technology based, in our study, on an FEI Quanta600F scanning electron microscope (SEM). The ' $\mathrm{F}$ ' designation refers to the field emission gun used as opposed to a normal tungsten filament SEM system. Results are obtained from the combination of image analysis employing atomic-number contrast imaging (from backscattered electron (BSE) signal intensity) and energy-dispersive spectrometry (EDS) (e.g. Fandrich and others, 2007) using two Bruker 5010 SDD detectors. Based on comparisons of semi-quantitative EDS and literature values, chemical compositions of each mineral were assigned and assays calculated by the MLA. X-ray diffraction (XRD) analysis was used to verify the mineralogy, using a Panalytical X'Pert Pro Diffractometer equipped with a Cu X-ray source. Accuracy of MLA data is conventionally evaluated on how close a calculated composition based on the mineralogy agrees with a direct assay. The reproducibility of individual measurements is $0.3 \%$ mineral on average. Further information about the specific processes can be found at http://www.actlabs.com.

Visual analysis of grains from the cryoconite samples was performed using a SEM (Zeiss ${ }^{\circledR}$ SUPRA 55VP) and digital photography. In the latter case, the dried cryoconite material was displaced over a transparent support back-illuminated by means of an array of white light-emitting diodes (LEDs) facing the camera lens. This set-up was selected after several tests, as it was the one that reduced shadowing effects and increased the contrast of the images. The images were then analysed with either ImagePro ${ }^{\circledR}$ software or a

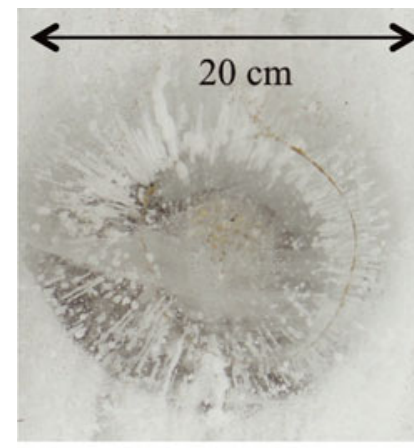

a

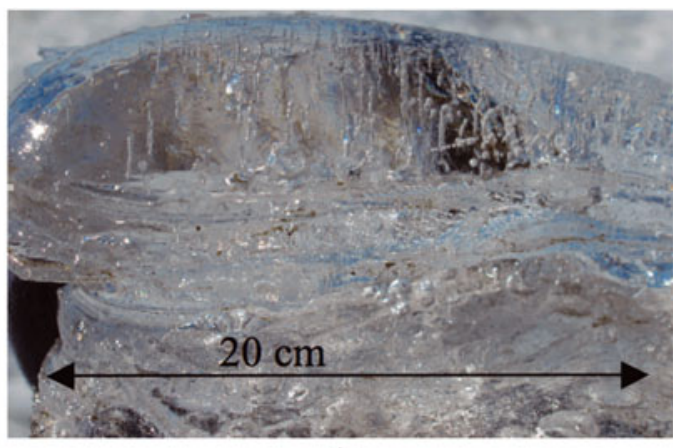

b

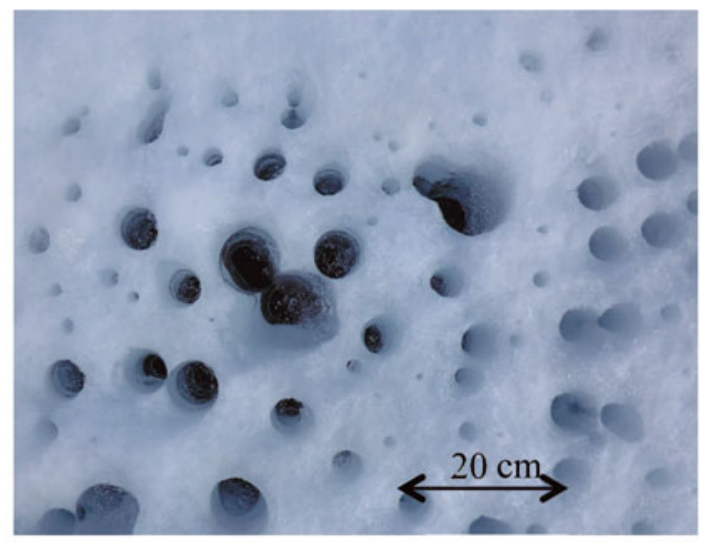

c

Fig. 3. Cryoconite holes used for sampling in (a, b) Antarctica and (c) Greenland. 
Table 1. Results of the mineralogical analysis of the samples from Greenland and Antarctica

\begin{tabular}{|c|c|c|c|c|}
\hline & \multicolumn{2}{|c|}{ Greenland } & \multirow[b]{2}{*}{ Average } & \multirow{2}{*}{$\begin{array}{l}\text { Antarctica } \\
\text { Std dev. }\end{array}$} \\
\hline & Average & Std dev. & & \\
\hline Quartz & 20.50 & 0.76 & 13.60 & 0.95 \\
\hline K_Feldspar & 9.80 & 0.40 & 8.10 & 0.71 \\
\hline Albite & 16.20 & 0.32 & 5.70 & 0.50 \\
\hline Plagioclase & 36.10 & 0.56 & 34.80 & 1.02 \\
\hline Amphibole & 11.40 & 0.38 & 20.30 & 0.97 \\
\hline Augite & 1.10 & 0.06 & 3.90 & 0.44 \\
\hline Orthopyroxene & 0.50 & 0.00 & 0.80 & 0.17 \\
\hline Epidote & 0.60 & 0.06 & 0.40 & 0.06 \\
\hline Phlogopite_\&_Biotite & 0.60 & 0.06 & 5.40 & 0.35 \\
\hline Talc & $<0.1$ & 0 & 1.00 & 0.32 \\
\hline Chlorite & 1.70 & 0.21 & 2.80 & 0.55 \\
\hline Illite/Muscovite & 0.30 & 0.06 & 1.10 & 0.38 \\
\hline Kaolinite & $<0.1$ & 0 & $<0.1$ & 0 \\
\hline Sphene & $<0.1$ & 0 & 0.20 & 0.06 \\
\hline Apatite & $<0.1$ & 0 & 0.30 & 0.12 \\
\hline Fe_Sulphate_Clay & n.d. & 0 & $<0.1$ & 0 \\
\hline Goethite & 0.30 & 0.06 & $<0.1$ & 0 \\
\hline Jarosite & n.d. & 0 & $<0.1$ & 0 \\
\hline Titanite & 0.20 & 0.00 & 0.60 & 0.23 \\
\hline Carbonates & $<0.1$ & 0 & $<0.1$ & 0 \\
\hline Ilmenite & 0.30 & 0.17 & 0.40 & 0.25 \\
\hline Rutile & $<0.1$ & 0 & $<0.1$ & 0 \\
\hline Magnetite_Ti & $<0.1$ & 0 & $<0.1$ & 0 \\
\hline Zircon & $<0.1$ & 0 & $<0.1$ & 0 \\
\hline Pyrite & $<0.1$ & 0 & $<0.1$ & 0 \\
\hline
\end{tabular}

n.d. $=$ not detected

Matlab ${ }^{\text {TM}}$-based image-analysis software. Highly magnified $(10 \times)$ photographs of the cryoconite were taken over the back light and then converted into black-and-white images and analysed for area, axis lengths and aspect ratio using Matlab ${ }^{\text {TM }}$ functions. Multiple photographs from the same sample were taken, resulting in an overall sample size of $\sim 1000$ particles for the samples from Greenland and $\sim 980$ particles for the samples from Antarctica.

\section{Organic matter and carbonate}

The following steps were performed to quantify the amount of organic matter and carbonate in the samples, building on prior work by Dean (1974), Takeuchi and others (2001) and Takeuchi and Li (2008). In the first stage, the sample was placed in an oven in a pre-weighed ceramic crucible at $105^{\circ} \mathrm{C}$ for 12 hours to remove moisture. The sample and the crucible were then weighed to obtain the dry weight and used as a basis for the weight loss calculations. The sample and the crucible were then placed in a muffle furnace at $500^{\circ} \mathrm{C}$ for 3 hours to combust the organic material. In a dried and powdered sample such as ours, the organic material starts igniting at $\sim 200^{\circ} \mathrm{C}$ and it is completely ignited by the time the furnace reaches $500^{\circ} \mathrm{C}$ (Dean, 1974). The sample and the crucible were cooled to room temperature and weighed. The difference between the dry weight and this weight represents the amount of organic carbon lost on ignition. The sample in the crucible was again placed in the furnace at $1000^{\circ} \mathrm{C}$ for 1 hour to remove calcium carbonate (Dean, 1974). The loss of weight between the second and the third sample represents the amount of $\mathrm{CO}_{2}$ evolved from carbonate.
In the following, we refer to these samples as $S_{d r y} x x$, $S_{500 \_x x}$ and $S_{1000 \_x x}$, with XX being Gr for the Greenland sites and An for the Antarctic sites. When XX is not specified, the discussion will refer to the samples from both locations. The weight of each sample before and after combustion was measured on a digital balance $( \pm 0.0001 \mathrm{~g})$. Organic matter determination and spectral measurements were performed on all $S_{d r y}, S_{500}$ and $S_{1000}$ samples. The accuracy of organic matter determination by means of the technique used here (e.g. loss-on-ignition, LOI) is affected by some major known factors. In general, the results concerning the amount of organic matter can be considerably overestimated because of various losses, which belong to volatile salts, organic compounds, structural water, sulphide oxidation or inorganic carbon (e.g. Heiri and others, 2001; Veres, 2002). For example, as reported in Veres (2002), eventual inorganic carbon will evolve $\mathrm{CO}_{2}$ at temperatures between $425^{\circ} \mathrm{C}$ and $520^{\circ} \mathrm{C}$ in minerals such as magnesite, rhodochrosite or siderite. Moreover, because of the way the technique is designed, any bias of $\mathrm{LOI}$ at $500^{\circ} \mathrm{C}$ will influence the results of $\mathrm{LOI}$ at $1000^{\circ} \mathrm{C}$. Studies reported in the literature indicate that the amount of organic matter determined by LOI at $\sim 500^{\circ} \mathrm{C}$ is considered to be 'approximately' twice the organic carbon content, with different conversion factors proposed for converting organic carbon to original organic matter content of a sample, ranging between 2.13 and 1.45 (Veres, 2002).

\section{Spectral measurements}

Reflectance in the 400-2500 nm range was measured in the laboratory using an ASD spectrometer and an ASD highintensity contact probe (www.asdi.com). The probe is designed for contact measurements of solid raw materials such as minerals, grains and other granular materials, which are illuminated by means of a halogen-calibrated light. Spectralon ${ }^{(}$tiles $(12.5 \mathrm{~cm} \times 12.5 \mathrm{~cm})$ were used as a reference target (2, 50, 75 and $99 \%$ reflectance) to evaluate instrument calibration before, during and after measurements and to characterize the error. For each sample, measurements were repeated after rotating the sample by an angle of $15^{\circ}$ under the probe and results were averaged. Spectral resolution for the ASD instrument is $3 \mathrm{~nm}$ at $700 \mathrm{~nm}$ and $10 \mathrm{~nm}$ above $1400 \mathrm{~nm}$. The sampling interval was $1.4 \mathrm{~nm}$ in the $350-1050 \mathrm{~nm}$ band and $2 \mathrm{~nm}$ in the 1000 $2500 \mathrm{~nm}$ band.

\section{RESULTS}

\section{Mineralogy, grain size and organic matter}

Results from the mineralogical analyses for the $S_{\text {dry_Gr }}$ and $S_{\text {dry_An }}$ samples are reported in Table 1 . The samples collected at the Greenland site contained a higher concentration of quartz $(20.5 \%)$ and albite $(16.2 \%)$ than the samples from Antarctica (13.6\% quartz and 5.7\% albite). Amphibole, augite, phlogopite/biotite, talc and chlorite are present in higher concentrations in the samples collected at Canada Glacier. Conversely, albite and goethite were found in higher concentrations in the samples from Jakobshavn Isbræ. The remaining minerals identified in both samples have similar concentrations.

Visual inspection of the cryoconite grains from the samples collected at the two sites reveals distinct differences in grain size and morphology. Figure 4 shows SEM and microscope images of grains from the cryoconite samples 


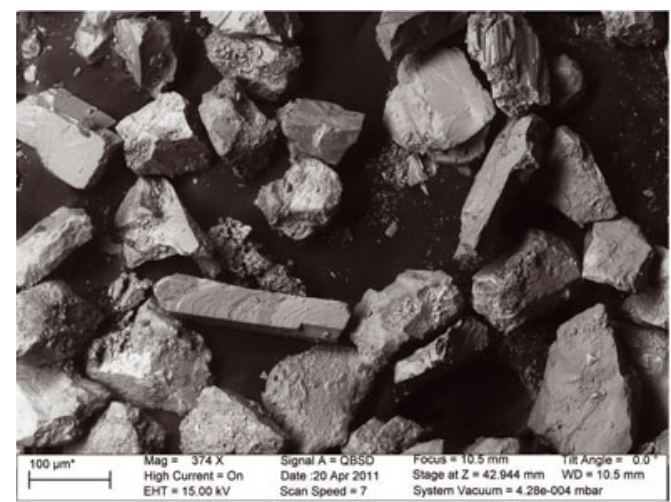

a

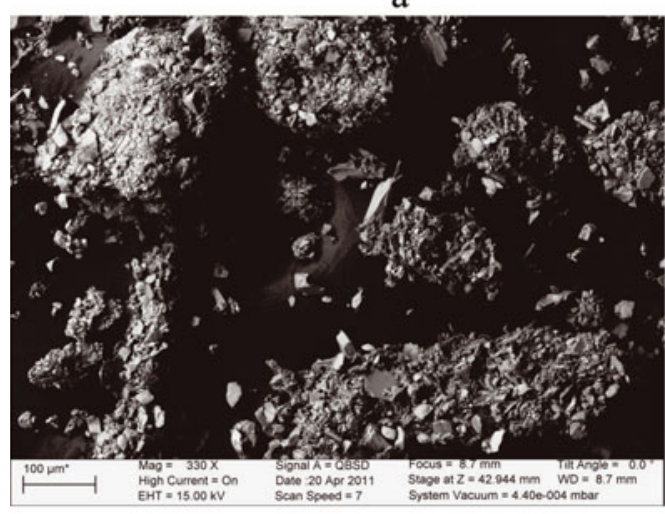

c

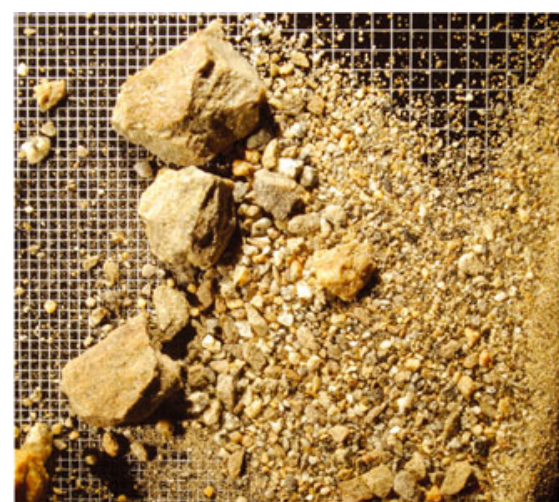

b

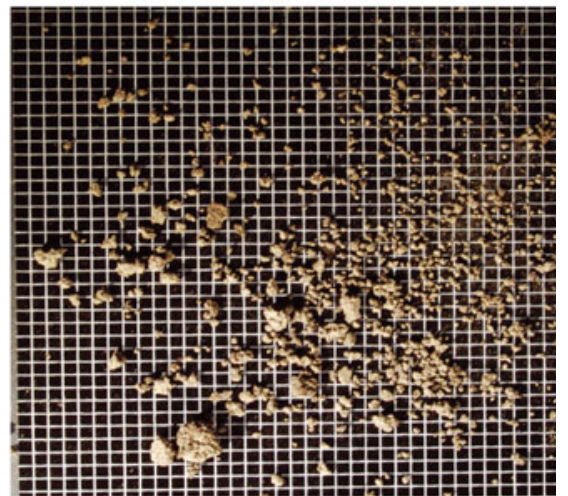

d

Fig. 4. (a, c) SEM and (b, d) microscope images of grains from (a, b) Canada Glacier and (c, d) Jakobshavn Isbræ cryoconite samples.

from the two locations. The pictures show the absence of clustering in the samples from the Antarctic site, with the grains appearing as distinct fragments of different sizes and shapes. Most grains have angular shapes and are characterized by sharp edges. As pointed out by Wientjes and others (2011), acute angles are typical for volcanic material but have also been observed in glacial grains. Conversely, the material from Greenland is composed of small particles clumped into relatively larger rounded agglomerates (Fig. 4c and $\mathrm{d}$ ). Figure 5 shows the histogram plots of the minor axes (Fig. $5 a$ and b), the major axes (Fig. $5 c$ and d) and the area (Fig. 5e and $f$ ) for the samples from the Greenland sites (Fig. 5a, c and e) and Antarctic sites (Fig. 5b, d and f). Most of the minor-axis values in the samples from Greenland lie below $0.5 \mathrm{~mm}$. The sample from Antarctica shows a higher diversity of particle sizes than the sample from Greenland. Analysis of the particle areas indicates that the samples from Greenland have an area generally below $0.5-0.6 \mathrm{~mm}^{2}$ while the samples from Antarctica can reach values up to 3.5$4 \mathrm{~mm}^{2}$. No substantial difference is evident in the aspect ratios. This differs from the results obtained in a previous study, which suggested that larger particles from cryoconite in Greenland might have a greater aspect ratio than smaller ones (Irvine-Fynn and others, 2010). The amount of organic matter obtained from LOI of Greenland samples was $9.3 \pm 1.2 \%$. The Antarctic samples contained less organic matter $(1.21 \pm 0.2 \%)$. Combustion at $1000^{\circ} \mathrm{C}$ further reduced the weight of the samples by $14.2 \pm 1.1 \%$ in the case of Greenland and $10.91 \pm 0.1 \%$ in the case of Antarctica. In total, after the two combustions, the Greenland samples lost $\sim 24 \%$ of their original dry weight, whereas those from Antarctica lost $\sim 12.1 \%$.

\section{Spectral reflectance}

The reflectance spectra of the samples from Jakobshavn Isbræ and Canada Glacier in the $400-2500 \mathrm{~nm}$ range are plotted in Figure 6. The reflectance spectra for the dry samples $\left(S_{\text {dry_}_{2} x}\right)$ from the two sites show comparable values, despite the differences in percentage of organic material. The shape and absolute values of the reflectance values for both samples are consistent with previously published results (e.g. Takeuchi, 2002). The removal of organic material considerably increases the reflectance of the samples from Greenland (Fig. 6a) for wavelengths above $\sim 500 \mathrm{~nm}$, with the difference between the reflectance of the $\mathrm{S}_{\text {dry_Gr }}$ and $\mathrm{S}_{500 \_G r}$ samples generally increasing until $\sim 1400 \mathrm{~nm}$ and remaining relatively constant above $1400 \mathrm{~nm}$, with a peak value of $\sim 0.1$. This corresponds to a relative increase in reflectance for the Greenland samples before and after the first combustion above $500 \mathrm{~nm}$ ranging between $\sim 110 \%$ and $\sim 160 \%$ (Fig. $6 \mathrm{c}$ ), with the peak occurring at $\sim 1700 \mathrm{~nm}$. Combustion of the Greenland samples at $1000^{\circ} \mathrm{C}$ further increased reflectance over most of the measured spectrum, with relatively small change occurring below $\sim 500 \mathrm{~nm}$. The absolute change in the reflectance between the $S_{1000 \_G r}$ and $S_{500 \_G r}$ samples is smaller than that associated with the difference between the $S_{500 \_G r}$ and $S_{\text {dry_Gr }}$ samples up to $\sim 1400 \mathrm{~nm}$, after which the changes are comparable (peaking at $\sim 0.15$ ).

Relative changes between the reflectance values of the $\mathrm{S}_{1000 \_G r}$ and $\mathrm{S}_{500 \_G r}$ samples are similar to the relative changes between $\mathrm{S}_{500 \_}$Gr and $\mathrm{S}_{\text {dry_Gr }}$ samples, though slightly smaller and ranging between $118 \%$ and $152 \%$ (black bars in Fig. 6c). In contrast to the samples from Greenland, removal 


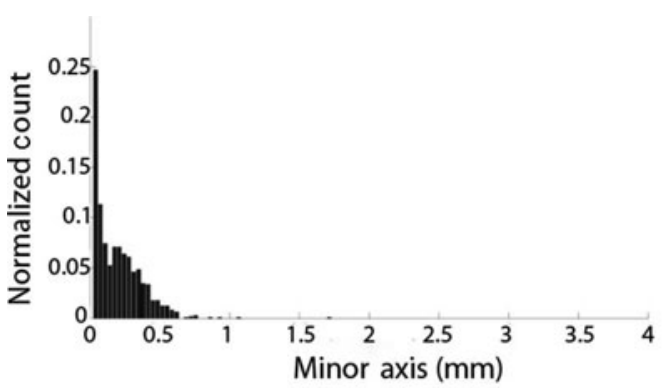

a

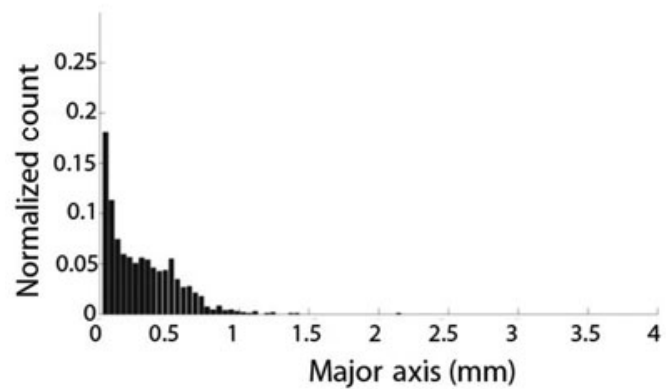

c

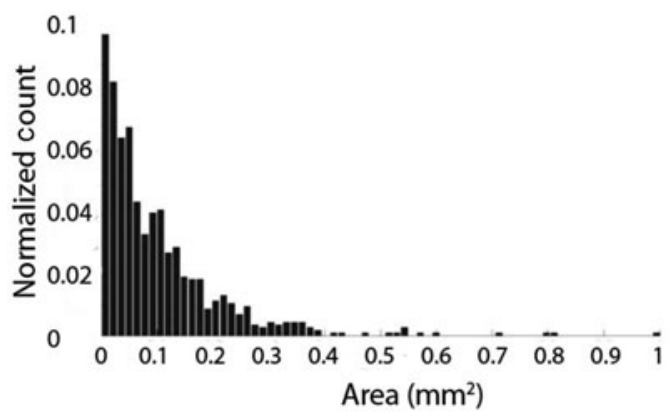

e

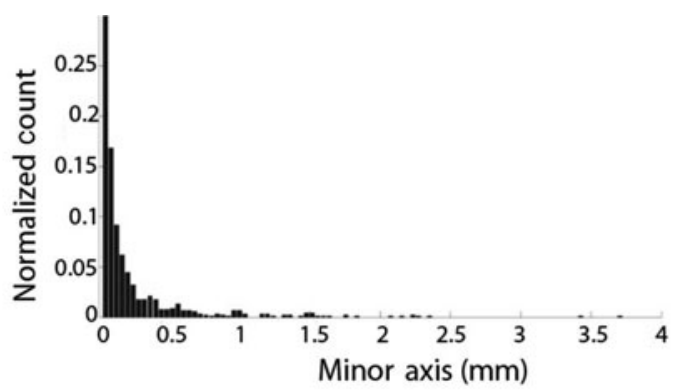

b

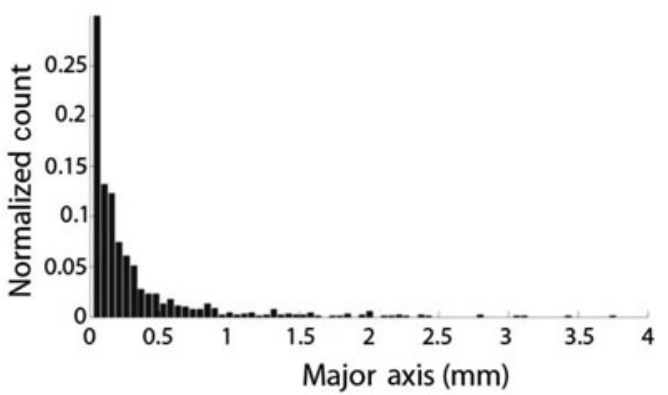

d

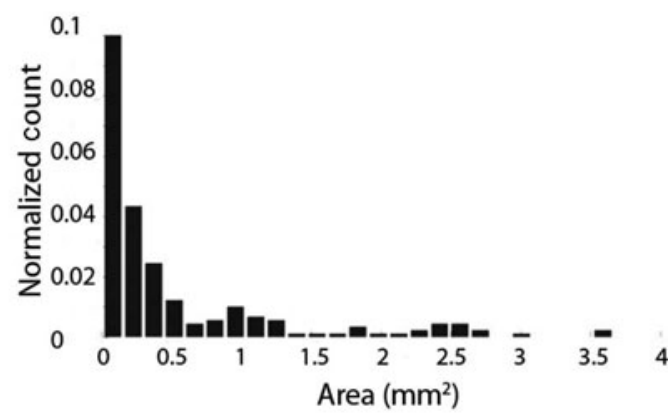

f

Fig. 5. Distribution of $(a, b)$ minor and (c, d) major axes and (e, f) surface area of the cryoconite grains in (a, c, e) Greenland and (b, d, f) Antarctic samples.

of organic matter from the samples collected at Canada Glacier did not considerably change the reflectivity along the measured spectrum (Fig. 6; e.g. $\sim 0.05$ below $\sim 700 \mathrm{~nm}$ and above $\sim 1800 \mathrm{~nm}$, hence falling within the measurement uncertainty). The reflectance values of the $S_{1000 \text { An }}$ samples are, however, much higher than those of the $S_{500 \_A n}$ samples, peaking at values up to $\sim 0.4$ at $\sim 2500 \mathrm{~nm}$ and showing an absolute increase of $\sim 0.1$ relative percentage $(\sim 140-170 \%)$. Figure $6 \mathrm{~d}$ shows the difference between the spectral reflectance values of Jakobshavn Isbræ and Canada Glacier samples measured after each combustion stage. The plot shows that the spectra of the $S_{\text {dry_Gr }}$ and $S_{\text {dry_An }}$ samples are similar across the measured spectrum. However, for the remaining two cases, the samples from Antarctica show a reduced reflectivity over those collected in West Greenland, still over the measured spectrum. The spectral values published by Bøggild and others (2010) are consistent with our study of Antarctic cryoconite following the removal of organics. Bøggild and others (2010) reported that the average spectral measurement of ice in Greenland's Kronprins Christians Land ranged between 0.2 and 0.6 as a function of percent cryoconite cover and ice morphology (Adhikary and others, 2000), whereas the albedo of wet cryoconite can be far lower (i.e. 0.04-0.1; Solberg and others, 2009; Bøggild and others, 2010).

\section{DISCUSSION}

The results of our mineralogical analysis are consistent with Hodson and others (2010b), who found that mineralogy of cryoconite from Svalbard was dominated by quartz, with lower concentrations of dolomite, orthoclase (feldspar), muscovite, biotite and kaolinite. Also, Stibal and others (2008) reported that cryoconite mineralogy from Svalbard lacked apatite and mainly consisted of chlorite, edenite (amphibole), quartz, albite, muscovite and unidentified amorphous clasts. Langford and others $(2010,2011)$ determined that quartz, feldspar, mica, kaolinite and dolomite were the main cryoconite minerals at their collection sites in Greenland and Svalbard. However, unlike Stibal and others (2008), they noted that apatite was present in minor amounts. Our mineralogical results are similar to other localities in the Northern Hemisphere. For instance, Takeuchi and others (2011) report that the inorganics associated with cryoconite 


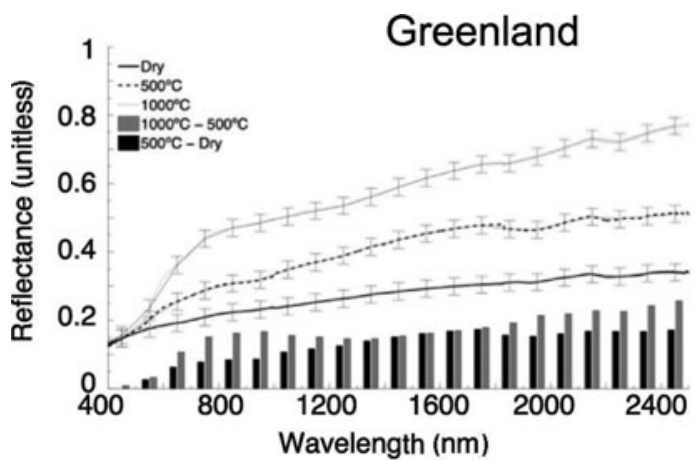

a

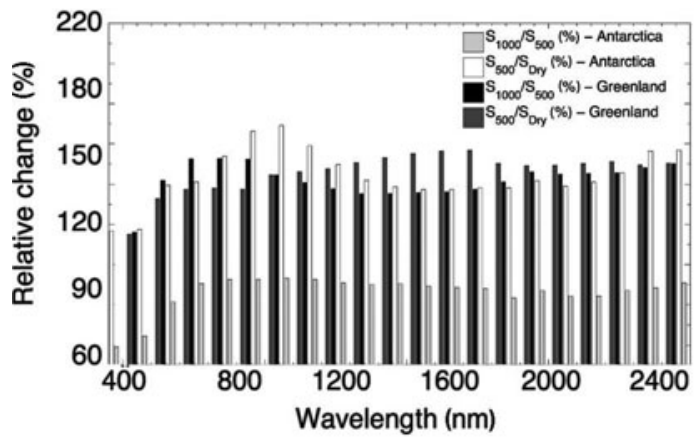

c

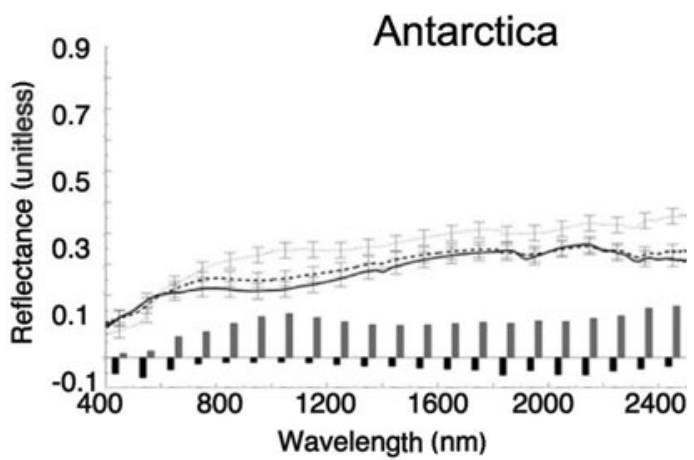

b

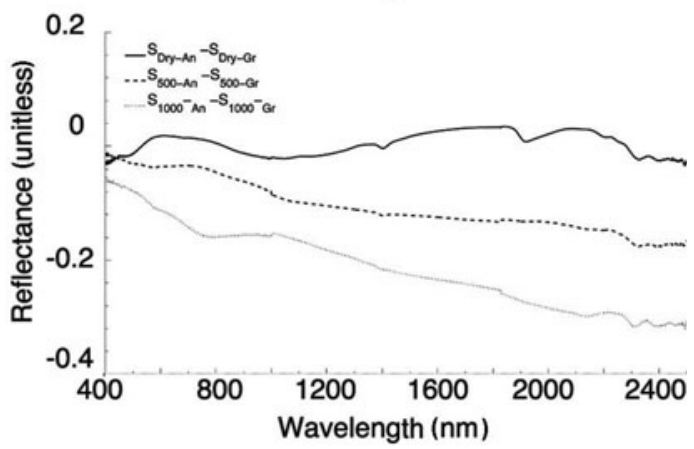

d

Fig. 6. Spectral reflectance for (a) Greenland and (b) Antarctic samples for $S_{\text {dry }}$ (solid line), $S_{500}$ (dashed line) and $S_{1000}$ (dotted line) and difference between the $S_{\text {dry }}$ and $S_{500}$ (black bars) and $S_{500}$ and $S_{1000}$ (grey bars) values. Error bars indicate the standard deviation computed from all measurements and are reported only every $100 \mathrm{~nm}$ to improve the readability of the figure. (c) Relative percentage difference between the reflectance values measured before and after the ignition. (d) Difference between the spectral reflectance values of Jakobshavn Isbræ and Canada Glacier samples measured after each combustion.

collected from Ürümqi glacier No. 1, Tien Shan, China, consist of the same types of minerals referenced above as well as a lesser fraction of amorphous clasts. Li and others (2011) also indicated that the cryoconite mineralogy from Ürümqi glacier No. 1 consists of nearly equal amounts of quartz and feldspar that account for $\sim 65 \%$ of the nodules and that the remaining fraction is divided between dark minerals (25\%) and clay minerals (10\%). Likewise, cryoconite in Laptev Sea (Russian Arctic) ice contains quartz, feldspar and an assortment of various clay minerals that are diagnostic of their source area, as well as low percentages of phyllosilicates and opaque materials (pyrite, siltstone, glauconite, amphibole) (Nürnberg and others; 1994). Moreover, Foreman and others (2007) reported that cryoconite material recovered from flooded holes in Antarctica's McMurdo Dry Valleys also consisted principally of the amphibole hornblende (dark-coloured), actinolite (lightcoloured) and to a lesser extent quartz. Bagshaw and others (2007) reported carbonates, sulfates and silicates as the likely mineral types in McMurdo Dry Valley cryoconite.

The mineralogical analysis of the samples from the two sites suggests that the samples from Jakobshavn Isbræ contain a higher percentage of minerals with relatively higher reflectance over the measured spectrum. Conversely, the samples from Canada Glacier contain a higher percentage of materials with relatively low reflectance. We do not have measurements of mineralogical composition of the areas surrounding the sampling site and can only speculate on the connection between the mineralogical composition of cryoconite and the local geology of each site. A geological map of Greenland was compiled by the Geological Survey of Denmark and Greenland (GEUS) and is available at http://www.geus.dk/program-areas/raw-materials-greenl-map/greenland/gr-map/kost_1-uk.htm. The map indicates that the Jakobshavn area is dominated by 'reworked amphibolite facies Archaean gneiss in early Proterozoic fold belts ( $\sim 3000 \mathrm{Ma}$ age $)^{\prime}$ (indicated with the classification \#74 in the map). Proterozoic basement rock (felsic igneous and metamorphic gneiss suites) appears to comprise the area encompassing Jakobshavn Isbræ (Weidick and Bennike, 2007; Henriksen and others, 2009). This could represent the prevailing local source of the cryoconite minerals in our samples based on the data presented in Table 1, which clearly documents the high concentration $(\sim 82 \%)$ of felsic minerals. A bedrock geologic map of the McMurdo Dry Valleys is also available at http://www. nrri.umn.edu/egg/REPORTS/MAP200802/MAP200802.html. The site where our Antarctic samples were collected is dominated by biotite orthogneiss (quartz, biotite, plagioclase, kspar gneiss of granitic composition). This might explain the higher content of biotite in the Antarctic samples compared with the ones from Greenland and the relatively high concentration of plagioclase. Moreover, Angino and others (1962) report that the exposures of the lower Taylor Valley contain metasedimentary, granitic and gneissic exposures and could account for the relatively high felsic content $(\sim 60 \%)$ observed in our cryoconite samples (Table 1). However, it is unclear where the mafic minerals 

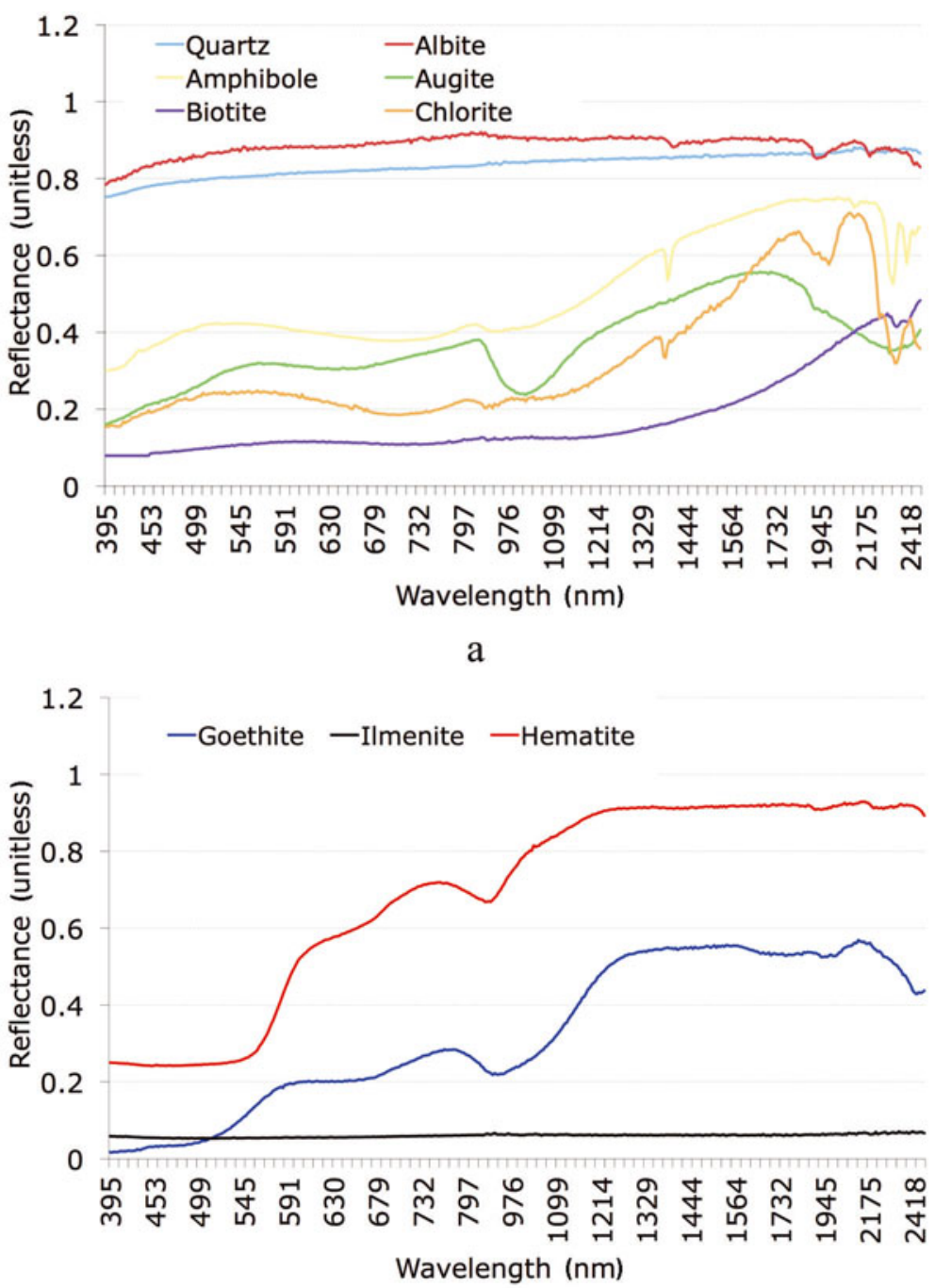

$\mathrm{b}$

Fig. 7. Examples of reflectance spectra $(400-2500 \mathrm{~nm}$ ) for (a) minerals with a percentage difference between the Greenland and Antarctic samples that is substantial and (b) oxides present in the samples or potentially forming after combustion.

$(\sim 25 \%)$ originate, although local metasedimentary sequences are one possibility.

Further analysis of the linkages between the regional geology and the sampling site is necessary to better understand the potential impact of the local material on the mineralogical composition of cryoconite. In particular, it is important to understand whether the samples collected at the two sites are representative of the areas surrounding the sampling sites. In this regard, systematic collection of samples from multiple sites spatially distributed over selected areas would provide information on the variability of the quantities reported here. Unfortunately, such a dataset is not available for the Antarctic site, and, to our knowledge, no funded project is currently focusing on this. We attempted to address this issue by collecting samples of cryoconite from multiple locations along the west coast of Greenland during the 2011 and 2012 field seasons. Those datasets are currently being analysed.

The difference between the spectra of the samples from the Antarctic and Greenland sites after removal of the organic matter can be explained by the differences in concentration of materials with different spectral properties. Indeed, the spectrum of a material can be decomposed into a weighted sum of the spectra of the so-called end-members, with the coefficients of the weighted sum representing the spectral abundance (related to the fraction of the endmember in the sample). In Figure 7 a we show the spectral reflectance of some minerals with different concentrations in the samples from the two sites (obtained from http:// speclab.cr.usgs.gov/spectral-lib.html). The higher percentage of minerals with lower reflectance in the Antarctic is likely responsible for the lower reflectance values of the samples from the Southern Hemisphere after the removal of organic matter. Conversely, a high percentage of minerals with high reflectance is responsible for the relatively high reflectance of the samples from Jakobshavn Isbræ.

The mineral composition in the case of Canada Glacier samples is likely responsible for the relatively small difference between the pre- and post-ignition reflectance values. We point out, however, that the percentage content of organic matter in the samples from Greenland is higher than that in the samples from Antarctica and this difference might reduce the reflectance of the samples from Greenland more than that of the samples from Antarctica. This, together with the mineralogical composition, is responsible for the large difference in the reflectance values of $S_{\text {dry_Gr }}$ and $S_{500 \_G r}$. Interestingly, the shape of the reflectance spectrum of the samples after the removal of organic matter is similar to that 
of materials containing oxides, consistent with Foreman and others' (2007) reporting iron hydroxide coatings on cryoconite material from the McMurdo Dry Valleys. Oxide minerals such as goethite and ilmenite are present in small amounts in the samples from the two sites, together with traces of jarosite and magnetite (Table 1). The spectra of goethite and ilmenite are plotted in Figure 7b (http:// speclab.cr.usgs.gov/spectral-lib.html). The reflectance curve of goethite is similar in shape to the curve of the $S_{1000} x x$ samples, suggesting that the presence of oxides might be responsible for the shape of the spectral reflectance. Nevertheless, the percentage of goethite and other oxides in the samples before the combustion appears to be too low to justify the observed shape of the reflectance spectrum. It is possible that oxides or clay-like material could form during the combustion process. These materials might change the bulk reflectance properties of the sample and would not be present in our current pre-combustion mineralogical analysis. The combustion of the samples might indeed produce a more oxidized form of goethite (e.g. gematite, with high reflectance in the red region; see Fig. 8), the spectrum of which is also shown in Figure 7b. Muscovite and iron chlorite may also be oxidized after the combustion.

Samples from Greenland and Antarctica show relatively higher reflectance values (up to 0.7 as in the case of the $\mathrm{S}_{1000 \_G r}$ sample) for wavelengths above $\sim 1000-1400 \mathrm{~nm}$. In most previously published work, spectral measurements are collected up to the near-infrared, with the exception of a few studies (e.g. Bøggild and others, 2010). The impact of cryoconite in the shortwave infrared region on the energy balance of ice and snow cryoconite-covered surfaces is, however, small or negligible. This is due to the very low absorption of solar radiation by snow- and ice-covered surfaces above $1400 \mathrm{~nm}$ (e.g. Grenfell and Perovich, 2004; Bøggild and others, 2010).

\section{CONCLUSIONS}

We have reported results from a comparative analysis of Jakobshavn Isbræ and Canada Glacier cryoconite samples aimed at quantifying and understanding the mineralogical, morphological and spectral differences and analogies between samples collected at the two sites. The sample from Greenland was composed mainly of relatively small particles clumped together into larger rounded particles, whereas the sample from Antarctica contained both fine and large particles with no agglomerates. The results of the mineralogical analysis showed different concentrations of minerals in the samples from the two locations. The material collected in Greenland contained a higher percentage of relatively brighter minerals, such as quartz and albite. In contrast, the material collected from the cryoconite holes in Antarctica contained a higher percentage of relatively dark minerals such as amphibole, augite and biotite. Other minerals, such as illite, sphene and apatite, were more abundant in the samples from Antarctica, though their concentration was generally low. Though biological material has been the subject of many past cryoconite studies, mineralogy also plays a key role in these systems. The cryoconite particles are, indeed, the main source of nutrients for biological activity because the surrounding glacial water is relatively pristine. Smith and others (2006) and Langford and others (2010) indicated that mineral heterogeneity influences the distribution of bacterial communities and

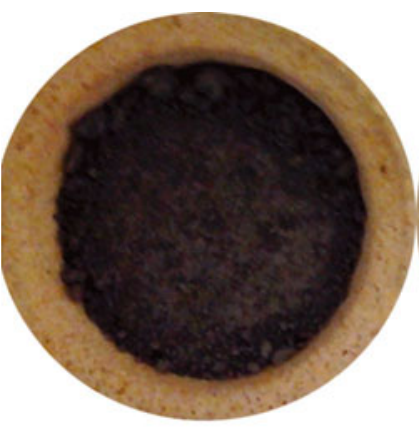

a

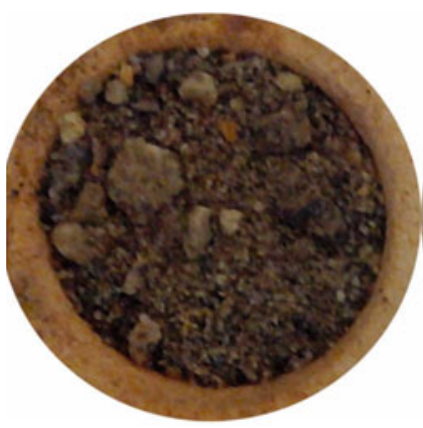

C

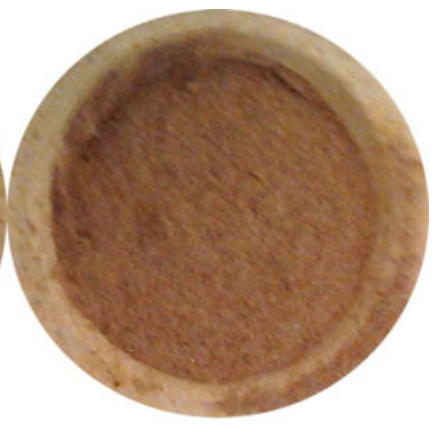

b

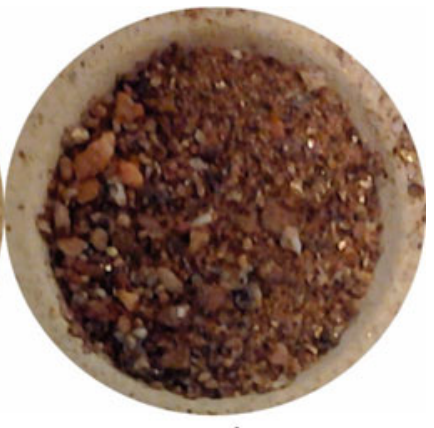

d
Fig. 8. Photographs of the material sampled from $(a, b)$ the Greenland site and (c, d) the Antarctic site in the crucible $(a, c)$ before and $(b, d)$ after the combustion. The diameter of each crucible is $1.25 \mathrm{~cm}$.

asserted that the physical parameters of minerals may be a key factor in the cryoconite-forming process. Specifically, kinetic dynamics between colliding colloidal grains can promote binding in the early stages of cryoconite agglomeration. Mineral grain enlargement eventually provides a suitable substrate for biofilms to form, furthering cryoconite growth and incorporation of larger suspended mineral grains into nodules by chemical adherence afforded by polymeric substances that are generated by the microbes.

Our data from spectral measurements in the laboratory confirm the primary role of organic material in reducing the reflectance over the measured spectrum $(400-2500 \mathrm{~nm})$ in the case of the sample from Jakobshavn Isbræ. The relatively negligible change in reflectance after the removal of organic matter in the case of the samples from Canada Glacier can be explained by the presence of a higher concentration of minerals with lower reflectance and by the relatively low amount of organic matter. Removal of calcium carbonate further increased reflectance of the samples from both sites for wavelengths above $\sim 500 \mathrm{~nm}$, reaching values up to $\sim 0.7$ in the shortwave infrared region. The relatively low reflectance in the visible and near-infrared region plays a key role in reducing the overall albedo of snow and ice surfaces covered by cryoconite, hence increasing the amount of absorbed solar radiation and favouring melting. However, the shortwave infrared portion of the spectrum plays a negligible role in the energy absorbed by ice covered by cryoconite in view of the low reflectance values of snow and ice in that region.

Our results suggest that it may be possible to apply remote-sensing tools to study the spatio-temporal variability of cryoconite, using, for example, high spatial resolution (1 m) multispectral data collected by commercial satellites 
(e.g. WorldView, QuickBird), as in Takeuchi and others (2006b) in the case of red algae in snow. Such an approach would likely be more successful when applied to samples similar to those from Greenland, where there exists a wellmarked difference between the reflectance of the cryoconite with and without organic content. Higher uncertainty might be present in the case of cryoconite similar to that collected from Canada Glacier, because of the relatively small difference between reflectance values when organic matter is present or absent. We plan to analyze in situ spectral data collected during the 2011 and 2012 field seasons in West Greenland (Jakobshavn and Kangerlussuaq) to investigate the development of a statistically robust relationship between albedo and the fraction of surface covered by cryoconite. We also plan to use the collected samples to investigate the presence of key elements that could provide clues to the origin of the materials within the holes.

\section{ACKNOWLEDGEMENTS}

We acknowledge the support of the US National Science Foundation through grant No. 0909388 of the NASA Cryosphere Program to M.T. and NSF OPP 0838970 to C.M.F. The World Wildlife Foundation is acknowledged for partially supporting fieldwork activities in Greenland. We also acknowledge the reviewers and the editor for constructive and helpful suggestions.

\section{REFERENCES}

Adhikary S, Nakawo M, Seko K and Shakya B (2000) Dust influence on the melting process of glacier ice: experimental results from Lirung Glacier, Nepal Himalayas. IAHS Publ. 264 (Symposium at Seattle 2000 - Debris-Covered Glaciers), 43-52

Anesio AM, Mindl B, Laybourn-Parry J, Hodson AJ and Sattler B (2007) Viral dynamics in cryoconite holes on a high Arctic glacier (Svalbard). J. Geophys. Res., 112(G4), G04S31 (doi: 10.1029/2006JG000350)

Angino EE, Turner MD and Zeller EJ (1962) Reconnaissance geology of lower Taylor Valley, Victoria Land, Antarctica. Geol. Soc. Am. Bull., 73(12), 1553-1561

Bagshaw EA, Tranter M, Fountain AG, Welch KA, Basagic $\mathrm{H}$ and Lyons WB (2007) Biogeochemical evolution of cryoconite holes on Canada Glacier, Taylor Valley, Antarctica. J. Geophys. Res., 112(G4), G04S35 (doi: 10.1029/2007JG000442)

Bøggild CE, Brandt RE, Brown KJ and Warren SG (2010) The ablation zone in northeast Greenland: ice types, albedos and impurities. J. Glaciol., 56(195), 101-113 (doi: 10.3189/ 002214310791190776)

Bossew P, Lettner $\mathrm{H}$ and Hubmer A (2006) A note on ${ }^{207} \mathrm{Bi}$ in environmental samples. J. Environ. Radioact., 91(3), 160-166

Bossew $\mathrm{P}$, Lettner $\mathrm{H}$, Hubmer $\mathrm{A}$, Erlinger $\mathrm{C}$ and Gastberger $\mathrm{M}$ (2007) Activity ratios of ${ }^{137} \mathrm{Cs},{ }^{90} \mathrm{Sr}$ and ${ }^{239+240} \mathrm{Pu}$ in environmental samples. J. Environ. Radioact., 97(1), 5-19

Christner BC, Kvito BH and Reeve JN (2003) Molecular identification of bacteria and eukarya inhabiting an Antarctic cryoconite hole. Extremophiles, 7(3), 177-183

Dastych H (2005) Macrobiotus ramoli sp. Nov., a new tardigrades species from the nival zone of the Ötzal Alps, Austria (Tardigrada). Mitt. Hamburg. Zool. Mus. Inst., 102, 21-35

Dean WE (1974) Determination of carbonate and organic matter in calcareous sediments and sedimentary rocks by loss on ignition; comparison with other methods. J. Sediment. Res., 44(1), 242-248

Fandrich R, Gu Y, Burrows D and Moeller K (2007) Modern SEMbased mineral liberation analysis. Int. J. Min. Process., 84(1-4), $310-320$
Foreman CM, Sattler B, Mikucki DL, Porazinska DL and Priscu JC (2007) Metabolic activity and diversity of cryoconites in the Taylor Valley, Antarctica. J. Geophys. Res., 112(G4), G04S32 (doi: 10.1029/2006JG000358)

Fountain AG and Tranter M (2008) Introduction to special section on microcosms in ice: the biogeochemistry of cryoconite holes. J. Geophys. Res., 113(G2), G02S91 (doi: 10.1029/ 2008JG000698)

Fountain AG, Tranter M, Nylen TH, Lewis KJ and Mueller DR (2004) Evolution of cryoconite holes and their contribution to meltwater runoff from glaciers in the McMurdo Dry Valleys, Antarctica. J. Glaciol., 50(168), 35-45 (doi: 10.3189/ 172756504781830312)

Fountain AG, Nylen TH, Tranter M and Bagshaw E (2008) Temporal variations in physical and chemical features of cryoconite holes on Canada Glacier, McMurdo Dry Valleys, Antarctica. J. Geophys. Res., 113(G1), G01S92 (doi: 10.1029/ 2007JG000430)

Grenfell TC and Perovich DK (2004) Seasonal and spatial evolution of albedo in a snow-ice-land-ocean environment. J. Geophys. Res., 109(C10), C1001 (doi: 10.1029/2003JC001866)

Gribbon PWF (1979) Cryoconite holes on Sermikavsak, West Greenland. J. Glaciol., 22(86), 177-181

Heiri O, Lotter AF and Lemcke G (2001) Loss-on-ignition as a method for estimating organic and carbon content in sediments: reproducibility and comparability of results. J. Paleolimnol., 25(1), 101-110

Henriksen N, Higgins AK, Kalsbeek F and Pulvertaft TCR (2009) Greenland from Archaean to Quaternary. Descriptive text to the 1995 Geological map of Greenland, 1:2 500 000. 2nd edition. Geol. Surv. Den. Greenland Bull., 18, 1-126

Hodson AJ and 6 others (2010a) The cryoconite ecosystem on the Greenland ice sheet. Ann. Glaciol., 51(56), 123-129 (doi: 10.3189/172756411795931985)

Hodson AJ and 6 others (2010b) The structure, biological activity and biogeochemistry of cryoconite aggregates upon an Arctic valley glacier: Longyearbreen, Svalbard. J. Glaciol., 56(196), 349-362 (doi: 10.3189/002214310791968403)

Irvine-Fynn TDL, Bridge JW and Hodson AJ (2010) Rapid quantification of cryoconite: granule geometry and in situ supraglacial extents, using examples from Svalbard and Greenland. J. Glaciol., 56(196), 297-308 (doi: 10.3189/ 002214310791968421)

Kikuchi Y (1994) Glaciella, a new genus of freshwater Canthyocamyidae (Copepoda Harpacticoida) from a glacier in Nepal, Himalayas. Hydrobiologia, 292/293, 59-66

Kim Y, Hatsushika H, Muskett RR and Yamazaki K (2005) Possible effect of boreal wildfire soot on Arctic sea ice and Alaska glaciers. Atmos. Environ., 39(19), 3513-3520 (doi: 10.1016/ j.atmosenv.2005.02.050)

Kohshima S (1984) A novel cold-tolerant insect found in a Himalayan glacier. Nature, 310(5974), 225-227

Kurat G, Koeberl C, Presper T, Brandstätter F and Maurette M (1994) Petrology and geochemistry of Antarctic micrometeorites. Geochim. Cosmochim. Acta, 58(18), 3879-3904

Langford H, Hodson A, Banwart S and Bøggild C (2010) The microstructure and biogeochemistry of Arctic cryoconite granules. Ann. Glaciol., 51(56), 87-94 (doi: 10.3189/ 172756411795932083)

Langford H, Hodson A and Banwart S (2011) Using FTIR spectroscopy to characterise the soil mineralogy of cryoconite from Aldegondabreen glacier, Svalbard. Appl. Geochem., 26(Supplement), S206-S209

Li D, Maa B, Jiang F and Wang P (2011) Nature, genesis and provenance of silt pellets on the ice surface of Glacier No. 1, upper Urumqi River, Tian Shan, Northwestern China. Quat. Int., 236(1-2), 107-115 (doi: 10.1016/j.quaint.2010.10.004)

Meese DA, Reimnitz E, Tucker WB, Gow AJ, Bischof J and Darby D (1997) Evidence for radionuclide transport by sea ice. Sci. Total Environ., 202(1-3), 267-278 
Mueller DR and Pollard WH (2004) Gradient analysis of cryoconite ecosystems from two polar glaciers. Polar Biol., 27(2), 66-74 (doi: 10.1007/s00300-003-0580-2)

Mueller DR, Vincent WF, Pollard WH and Fritsen CH (2001) Glacial cryoconite ecosystems: a bipolar comparison of algal communities and habitats. In Elster J, Seckbach J, Vincent WF and Lhotský $\mathrm{O}$ eds. Proceedings of the International Conference on Algae and Extreme Environments: Ecology and Physiology, 11-16 September 2000, Téeboñ, Czech Republic. (Nova Hedwigia Beiheft 123). J. Cramer/Gebr. Borntraeger, 173-197

Nansen F and G.C.H. (1891) Journey on the inland ice. J. Am. Geogr. Soc. New York, 23, 171-193

Nürnberg D and 7 others (1994) Sediment in Arctic sea ice: implications for entrainment, transport and release. Mar. Geol., 119(3/4), 185-214

Odell NE (1925) Observations on the rocks and glaciers of Mount Everest. Geogr. J., 66(4), 289-315

Pfirman SL, Eicken H, Bauch D and Weeks WF (1995) The potential transport of pollutants by Arctic sea ice. Sci. Total Environ. 159(2-3), 129-146

Pillinger CT, Kroto HW, Haddon RC, lijima S and Leach S (1993) Elemental carbon as interstellar dust [and discussion]. Phil. Trans. Phys. Sci. Eng., 343(1667), 73-86

Porazinska DL, Fountain AG, Nylen TH, Tranter M, Virginia RA and Wall DH (2004) The biodiversity and biogeochemistry of cryoconite holes from McMurdo Dry Valley glaciers, Antarctica. Arct. Antarct. Alp. Res., 36(1), 84-91

Reznichenko N, Davies T, Shulmeister J and McSaveney MJ (2010) Effects of debris on ice-surface melting rates: an experimental study. J. Glaciol., 56(197), 384-394 (doi: 10.3189/ 002214310792447725)

Säwström C, Mumford P, Marshall W, Hodson A and LaybournParry J (2002) The microbial communities and primary productivity of cryconite holes in an Arctic glacier (Svalbard $79^{\circ} \mathrm{N}$ ). Polar Biol., 25(8), 591-596

Smith JJ, Tow LA, Stafford W, Cary C and Cowan DA (2006) Bacterial diversity in three different Antarctic cold desert mineral soils. Microbial Ecol., 51(4), 413-421 (doi: 10.1007/s00248006-9022-3)

Solberg R and 6 others (2009) Remote sensing of black carbon in the Arctic. In Proceedings of the 33rd International Symposium on Remote Sensing of Environment (ISRSE-33), 4-8 May 2009. Stresa, Italy. Internatioal Center for Remote Sensing of Environment, Tucson, AZ

Stibal M, Tranter M, Telling J and Benning LG (2008) Speciation, phase association and potential bioavailability of phosphorus on a Svalbard glacier. Biogeochemistry, 90(1), 1-13 (doi: 10.1007/ s10533-008-9226-3)

Takeuchi N (2002) Optical characteristics of cryoconite (surface dust) on glaciers: the relationship between light absorbency and the property of organic matter contained in the cryoconite. Ann. Glaciol., 34, 409-414 (doi: 10.3189/172756402781817743)

Takeuchi N (2009) Temporal and spatial variations in spectral reflectance and characteristics of surface dust on Gulkana Glacier, Alaska Range. J. Glaciol., 55(192), 701-709 (doi: 10.3189/002214309789470914)

Takeuchi N and Li Z (2008) Characteristics of surface dust on Ürümqi Glacier No. 1 in the Tien Shan Mountains, China. Arct. Antarct. Alp. Res., 40(4), 744-750

Takeuchi N, Kohshima S, Yoshimura Y, Seko K and Fujita K (2000) Characteristics of cryoconite holes on a Himalayan glacier, Yala Glacier, central Nepal. Bull. Glaciol. Res., 17, 51-59

Takeuchi N, Kohshima S, Shiraiwa T and Kubota K (2001) Characteristics of cryoconite (surface dust on glaciers) and surface albedo of a Patagonian glacier, Tyndall Glacier, Southern Patagonia Icefield. Bull. Glaciol. Res., 18, 65-69

Takeuchi N, Dial R, Kohshima S, Segawa T and Uetake J (2006a) Spatial distribution and abundance of red snow algae on the Harding Icefield, Alaska, derived from a satellite image. Geophys. Res. Lett., 33(21), L21502 (doi: 10.1029/2006GL027819)

Takeuchi N, Uetake J, Fujita K, Aizen V and Nikitin S (2006b) A snow algal community on Akkem Glacier in the Russian Altai mountains. Ann. Glaciol., 43, 378-384 (doi: 10.3189/ 172756406781812113)

Takeuchi N, Ishida Y and Li Z (2011) Microscopic analyses of insoluble particles in an ice core of Ürümqi Glacier No. 1: quantification of mineral and organic particles. J. Earth Sci., 22(4), 431-440

Tieber A, Lettner H, Bossew P, Hubmer A, Sattler B and Hofmann W (2009) Accumulation of anthropogenic radionuclides in cryoconites on Alpine glaciers. J. Environ. Radioact., 110(7), 590-598 (doi: 10.1016/j.jenvrad.2009.04.008)

Tranter M and 6 others (2004) Extreme hydrochemical conditions in natural microcosms entombed within Antarctic ice. Hydrol. Process., 18(2), 379-387

Veres D (2002) A comparative study between loss on ignition and total carbon analyses on minerogenic sediments. Studia Universitatis Babes-Bolyai, Geologia, 48(2), 171-182

Weidick A and Bennike O (2007) Quaternary glaciation history and glaciology of Jakobshavn Isbræ and the Disko Bugt region, West Greenland: a review. (GEUS Bulletin 14). Geological Survey of Denmark and Greenland, Copenhagen

Wharton RA, Jr, Vinyard WC, Parker BC, Simmons GM, Jr and Seaburg KG (1981) Algae in cryoconite holes on Canada Glacier in southern Victoria Land, Antarctica. Phycologia, 20(2), 208-211

Wharton RA, Jr, McKay CP, Simmons GM, Jr and Parker BC (1985) Cryoconite holes on glaciers. BioScience, 35(8), 499-503

Wientjes IGM, Van de Wal RSW, Reichart GJ, Sluijs A and Oerlemans J (2011) Dust from the dark region in the western ablation zone of the Greenland ice sheet. Cryosphere, 5(3), 589-601 (doi: 10.5194/tc-5-589-2011) 